\title{
Enzime Dirençli Nişasta Kullanarak Fonksiyonel Galeta Geliştirilmesi
}

\author{
Gökçen Garipoğlu ${ }^{*}$ \\ ${ }^{1}$ Bahçeşehir Üniversitesi, Sağlık Bilimleri Fakültesi, Beslenme ve Diyetetik Bölümü (ORCID: 0000-0001-7430-5163)
}

(İlk Geliş Tarihi 17 Ocak 2019 ve Kabul Tarihi 4 Mart 2019)

(DOI: 10.31590/ejosat.514165)

\begin{abstract}
ATIF/REFERENCE: Garipoğlu, G. (2019). Enzime Dirençli Nişasta Kullanarak Fonksiyonel Galeta Geliştirilmesi. Avrupa Bilim ve Teknoloji Dergisi, (15), 375-380.

\section{$\ddot{O} \mathbf{z}$}

Bu çalışmada ülkemizde diyabet, kilo kontrolü gibi durumlarda sık tüketilen bir atıştırmalık olan galetaya işlevsel özellik kazandırılması amacıyla enzime dirençli nişasta (EDN) ilave edilerek yeni bir ürün geliştirilmesi amaçlanmıştır. Kimyasal olarak laboratuvar ortamında buğday nişastasından elde edilen enzime dirençli nişasta, galeta yapımında toplam un içeriğinin \% 10-15-20-30 ve 40 olacak şekilde ilave edilmiştir. Bu karışım ile pişirilen galetaların glisemik indeks değerleri in vitro olarak nişasta sindirimi baz alınarak ölçülmüş ve standart galeta ile karşılaştırılmıştır. Son ürünlerin makrobesin ögeleri, diyet lif miktarı, enerji değeri ve glisemik indeks değeri ölçülmüştür.

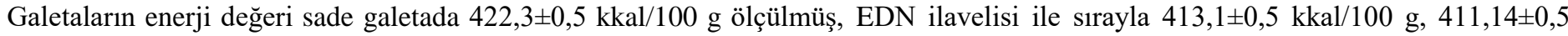
$\mathrm{kkal} / 100 \mathrm{~g}, 409,1 \pm 0,5 \mathrm{kkal} / 100 \mathrm{~g}, 406,06 \pm 0,5 \mathrm{kkal} / 100 \mathrm{~g}$ ve $398,66 \pm 0,5 \mathrm{kkal} / 100$ g’ye düşmüştür. Diyet lifi miktarı ise sade galetada $4,7 \pm 0,5 \mathrm{~g}$ iken, EDN oranı arttıkça17,27 $\pm 0,5$ g'a yükselmiştir. İn vitro glisemik indeks değeri sade galetada $85 \pm 1$ 'den sırasıyla $60 \pm 1$ $56 \pm 0,5$ - 54 $\pm 0,5$ - $52 \pm 0.05$ - 51 $\pm 0,5$ 'e düşmüştür.
\end{abstract}

Anahtar Kelimeler: Dirençli Nişasta, Fonksiyonel Besin, Galeta, Sağlık, Obezite

\section{Development of Functional Grissini Using Enzyme Resistant Starch}

\begin{abstract}
In this study, it is aimed to develop a new product by adding enzyme resistant starch (RS) in order to provide a functional property to grissini, which is a frequently consumed snack in cases such as diabetes and weight control in our country. Enzyme-resistant starch obtained from wheat starch in the laboratory environment was added to the grissini as the amount of 10-15-20-30 and 40\% of the total flour content in the grissini. The glycemic index values of the grissini containing the RS were measured as in vitro method based on starch digestion and the values were compared with the standard one. Macronutrients, fiber content, energy value and the glycemic index value of end products were measured. The energy value of the grissini was measured as 422,3 $\pm 0,5 \mathrm{kcal} / 100 \mathrm{~g}$ on a without RS and $413,1 \pm 0,5 \mathrm{kcal} / 100 \mathrm{~g}, 411,14 \pm 0,5 \mathrm{kcal} / 100 \mathrm{~g}, 409,1 \pm 0.5 \mathrm{kcal} / 100 \mathrm{~g}, 406,06 \pm 0,5 \mathrm{kcal} / 100 \mathrm{~g}$ and $398,66 \pm 0,5 \mathrm{kcal} / 100 \mathrm{~g}$ respectively, by the addition of RS. The amount of dietary fiber was $4.7 \pm 0.5 \mathrm{~g}$ on the pure grissini, while the RS ratio increased, the dietary fiber amount increased to $17.27 \pm 0.5 \mathrm{~g}$. In vitro glycemic index value decreased from $85 \pm 1$ to $60 \pm 1-56 \pm 0,5-54 \pm 0,5-$ $52 \pm 0.05-51 \pm 0,5$, respectively.
\end{abstract}

Key Words: Resistant Starch, Functional Food, Grissini, Health, Obesity

\footnotetext{
1 Sorumlu Yazar: Bahçeşehir Üniversitesi, Sağlik Bilimleri Fakültesi, Beslenme ve Diyetetik Bölümü, ORCID: 0000-0001-7430-5163, gokcen.garipoglu@hes.bau.edu.tr
} 


\section{Giriş}

Yıllar içerisinde dünyada teknolojiden, gıda üretimine kadar pek çok alanda görülen gelişmeler yaşam biçimlerinin ve beslenme alışkanlıkların da değişmesine sebep olmuştur. Özellikle kentleşme ile geleneksel beslenme kültüründen uzaklaşma ve hızlı hazır besinlerin tüketimi artmıştır. Bu artış beslenmede doymuş yağ, şeker ve tuz içeriğinin artmasına, özellikle diyet lifi ile bazı vitamin ve minerallerin de yetersiz alınmasına yol açmıştır (TSB Mevzuatı, 2010-2014; TÜBER, 2015).

Türkiye'de yapılan beslenme ve sağlık araştırmalarının sonuçlarına göre obezite ve kardiyovasküler hastalıklar, tip II diyabet, bazı kanser türleri gibi beslenmeye bağlı bulaşıcı olmayan kronik hastalıklar toplumda sıklıkla görülmektedir (ÇSGB Yayını, 2016). Bu durum artan tedavi maliyetleri ile hem ekonomik kayıplara hem de sosyal sorunlara neden olarak bireylerin yaşam kalitesini bozmakta hatta yaşam süresinin kısalmasına da neden olmaktadır (TÜBER, 2015).

Beslenme insan gereksinimlerinin başında gelir ve besinler insan sağlığını iyileştirmeyi sağlayan pek çok biyobileşen içerir (Baysal, 2018; Gul ve ark., 2016). Besinlerde bulunan ve sağlık faydaları yüksek olan fonksiyonel bileşenler temel olarak biyoaktif karbonhidratlar (CHO), biyoaktif peptidler, çoklu doymamış yă̆ asitleri, vitamin ve mineraller ile fitokimyasallar olarak sınıflandırılabilir (Hasler ve ark., 2014). Son 50 yıldır epidemiyolojik veriler özellikle bitkisel kaynaklı biyoaktif bileşenlerin (meyveler, sebzeler, tam tahıllar) ve diyet lifinin kronik hastalık (Obezite, diyabet, kanser vb.) riskinde azalma ve/veya iyileşme üzerine güçlü etkilerini ortaya koymaktadır (Balsano ve Alisi, 2009; Gul ve ark., 2016).

BiyoaktifCHO türü olan EDN, kuru baklagiller, tam tahıllar, patates ve yeşil muz gibi besinlerde bulunur. İnce bağırsakta sindirime dirençli yapısı nedeniyle besinlerin glisemik indeksi düşürür ve postprandiyal kan glukozunu iyileştirir (Robertson, 2012). Dirençli nişastanın yavaş sindirilmesi kan glukoz seviyesinin daha iyi kontrol edilmesi ve buna bağlı olarak depo yağların kullanılmasını artırır. Ayrıca kan glukozu üzerine kontrollü etki göstermesi açlık hissini baskıladığı için toplam enerji alımının azalmasını sağlar ve kilo kontrolüne destek olur. Bu nedenle obezite tedavisinde EDN içeren besin tüketiminin artırılması önerilmektedir (Robertson, 2012; EFSA, 2011).

Dirençli nişastanın genel kabul gören bu yararlı etkilerinin yanında lipid metabolizması ve minerallerin biyoyararlılığını olumlu yönde etkileyebilmektedir. Enzime dirençli nişasta (Miller ve ark., 1995) kullanımının potansiyel faydalı kullanım alanları; diyabet, obezite, kolon kanseri, immün sistem hastalıkları ve diğer kanser türleri ve kardiyovasküler hastalıklar (KVH) olarak tanımlanmıştır (Bindels ve ark., 2015).

Avrupa Gıda Birliği Kurumu (EFSA), 2011 yılında dirençli nişasta için fonksiyonel sağlık beyanlarını onaylamış ve CHO yönünden zengin fırıncılık ürünlerinde belli oranlarda EDN kullanımının tokluk kan şekeri ve insülin düzenlenmesine yardımcı olabileceğine ilişkin olumlu görüş bildirmiştir (EFSA, 2011). Böylece EFSA'nın onayı ile birlikte dirençli nişastanın yüksek CHO içerikli fırıncılık ürünlerinde kullanımına yönelik inovasyonların da önü açılmıştır (EFSA, 2011; Fujii ve ark., 2013).

Hastalıklardan korunmada ve daha sağlıklı bir yaşama ulaşmada etkinlik gösteren inovatif ve geleneksel besinler "Fonksiyonel Besin" olarak tanımlanmış, "Food For Specified Health Uses (FOSHU)" kavramı ile sunulan fonksiyonel besinlere ilgi 1990'lardan sonra tüm dünyaya yayılmıştır (Hacıoğlu ve Kurt, 2012; Shimizu, 2012).

Dünyada fonksiyonel besinlerin pazar payı her y1l \% 10 büyümektedir. Bu pazarda süt ürünlerinden sonra \% 25,9'luk oranla unlu mamüller 2. sırada yer almaktadır. Türkiye'de ise, fonksiyonel gıda pazarı, özellikle son beş yılda büyük gelişme göstermiş, artan sağlık bilinci ve tüketicilerin fonksiyonel gıda ürünlerine yönelik talebine paralel olarak, birçok firma, pazara fonksiyonel gıdalar sunmaya başlamıştır (Hacıoğlu ve Kurt, 2012). 2013 yılında 43,2 milyar dolar büyüklüğe ulaşan fonksiyonel gıda ve içecek pazarının \% 25 büyüyeceği ve 2017 yılında 54 milyar dolar büyüklüğe ulaşacağı tahmin edilmektedir. Özellikle 2000'li yıllarda "sağlı", tüketicilerin satın alma kararını birinci sırada etkileyen kriter haline gelmiş, tüketicinin besinden beklentisi değişmiştir. Tüketim talebini destekleyen uygulamalar da bu alandaki arzı artmaya da devam edecektir (Hacıoğlu ve Kurt, 2012; Kranz ve ark., 2012).

$\mathrm{Bu}$ çalışmada beslenmemizde sık tüketilen firıncılık ürünlerinden galetaya çeşitli oranlarda dirençli nişasta ilave edilerek enerjisi azaltılmış, düşük glisemik indeksli ve yüksek lifli bir fonksiyonel besin geliştirmek amaçlanmıştır.

\section{Materyal ve Yöntem:}

Un, su, sıvıyağ, tuz ve ticari maya olarak bilinen Saccharomyces cerevisiae ile farklı oranlarda dirençli nişasta ilavesi yapılarak hazırlanan hamurlardan yapılan galetalar üst sıcaklığ $250^{\circ} \mathrm{C}$, alt sıcaklığı $175^{\circ} \mathrm{C}$ olan firında $45 \mathrm{dk}$ süresince pişirilerek 5 farklı galeta elde edilmiştir.

Sade, $\% 10, \% 20, \% 30$ ve \% 40 oranında buğday dirençli nişastası içeren galetalara nem, kül, protein, yăg ve toplam sindirilebilir $\mathrm{CHO}$ analizleri yapılmış ve değerler 100 gram üzerinden hesaplanmıştır. Nem, kül, yăg, protein ve toplam sindirilebilir CHO sonuçlarının toplamı 100'den çıkarılarak numunelerdeki diyet lif miktarı ve kalori değerleri hesaplanmıştır. Analizler paralel olacak şekilde tekrarlanmıştır (Elgün ve ark., 2001; AOAC International, 2010; High Speed Analysis of Amino Acids by Pre-Column Derivatization, 1999; Büyüktuncel, 2012; Goni ve ark., 1997; Buyken ve ark., 2018; Megazyme, 2005).

Besin ögelerinin ve bütün bileşenlerin birim ağırlığının sağladığı kullanılabilir enerji değerinin hesaplanması için Türk Gıda Kodeksi, Etiketleme Yönetmeliği Ek 10'da bulunan 'enerji çevrim faktörleri' kullanılmıştır. Dirençli Nişastanın enerjisi 0,4 kkal/g olarak kullanılmıştır (TGK, 2017; TURKOMP, 2019; Campbell, 2008). Nem, kül, yağ, protein ve toplam sindirilebilir CHO sonuçlarının toplamı 100'den çıkarılarak numunelerdeki diyet lif miktarı hesaplanmıştır (TGK, 2017). 
Nişasta sindirim hızları ölçülen numunelerin referans besin olan beyaz ekmek hidrolizi üzerinden hidroliz indeksi hesaplanmıştır. In vitro glisemik indeks değeri Goni metodu (Gí=39.71x0.549Hİ) kullanılarak hesaplanmıştır (Goni ve ark., 1997) Glisemik indeks aralıkları; $\geq 70$ Yüksek, 56-69 Orta ve $\leq 55$ Düşük olarak kabul edilmiştir (TSB Yayını, 2008).

\section{Bulgular ve Tartışma:}

Analizler sonucunda elde edilen sonuçlardan makro besin ögeleri miktarı ve enerji değerleri Tablo 1'de gösterilmiştir. Sade ve EDN içeren galetalarda protein oranı EDN ilavesi arttıkça düşük oranda azalmış ( $\% 0,16$ azalma), yağ değerleri değişmemiştir. Toplam

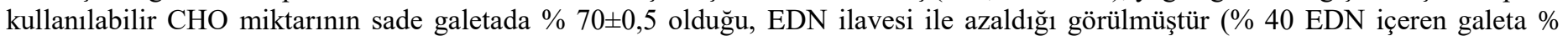

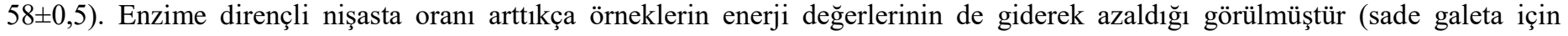
$422,3 \pm 0,5 \mathrm{kkal} / 100 \mathrm{~g}, \% 40 \mathrm{EDN}$ içeren galeta için 398,66 $\pm 0,5 \mathrm{kkal} / 100 \mathrm{~g}$ ). Protein içeriğindeki azalma ilave edilen EDN nedeniyle unun toplam nişastasındaki artışa, dolayısıyla unun kompozisyonunun değişmesine bağlanabilir. Enzime dirençli nişasta oranı artan galetalarda, kullanılabilir $\mathrm{CHO}$ azaldığından, sindirime ve emilime uğrayan CHO'da azalmış, dolayısıyla toplam enerji değeri düşmüştür.

Analiz sonuçları değerlendirildiğinde, galetaların EDN oranı arttıkça diyet lifi miktarı artııştır. Sade galetada $\% 4,7 \pm 0,5$ olan diyet

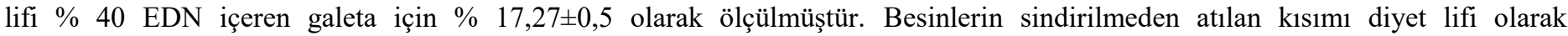
değerlendirilmektedir. Unlardaki nişastanın bir kısmının sindirime dirençli hale getirilmesi ile diyet lifi içeriği artırılabilir.

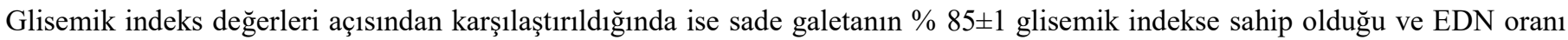
arttıkça bu değerin \% 51 10,05 'e kadar azaldığı görülmüştür. Diyet lifi içeriği yüksek besinlerin glisemik indeksi daha düşüktür. Bu sonuçlara göre, EDN ilavesi ile galetaların diyet lifi miktarı arttığından glisemik indeks değerinin düşmesine katkı sağladığı değerlendirilmiştir. Diyet lif miktarı ve glisemik indeks değerleri Tablo 2'de gösterilmiştir.

Toplumda artan obezite, diyabet, kalp damar hastalıkları gibi hastalıklar önemli bir halk sağlığı sorunudur. Bu sorunun temel sebeplerinin başında yanlış ve/veya aşıı beslenme gelmektedir. Modern hayatın hızlanan temposunda bireyler sağlıklı beslenmek için daha fazla çaba ve para harcamak zorunda kalmakta, ekonomik gücü yeterli olmayanların ise temel besinini yüksek CHO'lu unlu besinler oluşturmaktadır (Schmier, 2014). Bu nedenle toplumun çoğunluğu tarafından tüketilen bu ürünlere dirençli nişasta ilavesi ile diyet lifi içeriği artırlabilir, obezite, diyabet, sindirim sistemi kanserleri ve KVH gibi kronik hastalıkların riski de azaltılabilir (Birt, 2013; Guine ve ark., 2016).

Diyetle alınan lif miktarı ile ilgili olarak pek çok araştırma yapılmış, diyet lifi ile hastalıklar arasındaki ilişkiler ve diyet lifinin potansiyel sağlık faydaları gösterilmiştir (TÜBER, 2015; Chen ve ark., 2017; Veronense ve ark., 2018).

Tablo 1: Galetaların Makrobesin Ögeleri Miktarları ve Enerji Değerleri

\begin{tabular}{ccccc}
\hline Numuneler & Protein (\%) & Yağ (\%) & CHO (\%) & Enerji (kkal/100 g) \\
\hline Sade Galeta & $1,95 \pm 0,09$ & $13,9 \pm 1,9$ & $70 \pm 0,5$ & $422,3 \pm 0,5$ \\
$10 \%$ EDN içeren galeta & $1,95 \pm 0,04$ & $13,9 \pm 1,9$ & $65 \pm 0,5$ & $413,1 \pm 0,5$ \\
$15 \%$ EDN içeren galeta & $1,79 \pm 0,04$ & $13,9 \pm 1,9$ & $64 \pm 0,5$ & $411,14 \pm 0,5$ \\
$20 \%$ EDN içeren galeta & $1,79 \pm 0,04$ & $13,9 \pm 1,9$ & $63 \pm 0,5$ & $409,1 \pm 0,5$ \\
$30 \%$ EDN içeren galeta & $1,79 \pm 0,05$ & $13,9 \pm 1,9$ & $62 \pm 0,5$ & $406,06 \pm 0,5$ \\
$40 \%$ EDN içeren galeta & $1,79 \pm 0,06$ & $13,9 \pm 1,9$ & $58 \pm 0,5$ & $398,66 \pm 0,5$
\end{tabular}

Lif içeriği yüksek besinlerin günlük beslenmede artırılması çiğneme için harcanan zamanı artıracağından kilo kontrolüne destek olur. Lifli besin tüketimi ile glukoz emilimi yavaşlar ve dolayısıyla insülin yanıtını iyileşir. Diyet lifi ince bağırsakta kolesterol emilimini azaltarak kalp damar hastalıkları riskini de azaltır (Chen ve ark., 2017; Veronese ve ark., 2018).

Diyet lifinin yetişkinlerde günlük 20-35 g olarak alınması önerilmektedir. Ayrıca bu miktarın 5-8 g'ının da prebiyotik etkisi yüksek lifler (inülin, beta glucan, pektin vb.) olması önerilmektedir (Schmier ve ark., 2014; TÜBER, 2015). Yapılan bir çalışmada kadınların sadece \% 3'ünün, erkeklerin ise \% 6'sının önerilen diyet lifini karşıladığı gösterilmiştir. Çalışmada aynı zamanda diyet lifinde 1 gr artı̧̧ sağlandığında, kabızlıkta \% 1,9 oranında iyileşme olduğu bildirilmiş, günlük lif alımında ortalama günde $9 \mathrm{~g}$ artış sağlandığında hem kabızlığa bağlı hastalıklarda azalma, hem kabızlık tedavisinde kullanılan ilaç, bitkisel desteklerde azalma sağlanacağı, hem de çalışma saatlerinden kayıpların azalmasıyla yıllık 12 milyar dolar tasarruf edilebileceği ön görülmüştür (Schmier ve ark., 2014).

Tahıla dayalı beslenmede işlenmiş un kullanımı nedeniyle, elde edilen ürünler lif kaybına uğradığından özellikle bu ürünlere EDN ilavesi diyet lifi alımını artırmada etkili bir yol olabilir. Enzime dirençli nişasta sindirilmeden kolona ulaşması nedeniyle prebiyotik etki 
gösteren bir diyet lifidir (Stewart ve Zimmer, 2015; Zhang ve ark., 2015). Prebiyotik liflerin kolonda fermentasyonu sonucu k1sa zincirli yağ asitlerinin (KZYA) oluşumu artar, bu da bağırsak epiteli için enerji kaynağı olarak kullanılır.

Kısa zincirli yağ asitleri kolonda bulunan probiyotik bakterilerin çoğalmasını sağlayarak, bağışıklık sistemini destekler ve gastrointestinal sistem kanserleri başta olmak üzere pek çok kronik hastalıktan korunmaya ve iyileşmeye katkı sağlar (Birt ve ark., 2013; Gul ve ark., 2016).

Tablo 2: Galetaların Diyet Lif Miktarları ve Glisemik İndeks Değerleri

\begin{tabular}{ccc}
\hline Numuneler & Diyet Lif $(\%)$ & GI $(\%)$ \\
\hline Sade Galeta & $4,7 \pm 0,5$ & $85 \pm 1$ \\
$10 \%$ EDN içeren galeta & $10,1 \pm 0,5$ & $60 \pm 1$ \\
$15 \%$ EDN içeren galeta & $11,05 \pm 0,5$ & $56 \pm 0,5$ \\
$20 \%$ EDN içeren galeta & $12,44 \pm 0,5$ & $54 \pm 0,5$ \\
$30 \%$ EDN içeren galeta & $12,96 \pm 0,5$ & $52 \pm 0,005$ \\
$40 \%$ EDN içeren galeta & $17,27 \pm 0,5$ & $51 \pm 0,05$
\end{tabular}

Plasebo kontrollü, çift kör olarak yapılan bir çalışmada 26 gönüllüye 12 hafta boyunca normal un ve 12 hafta boyunca da \% 30 DN içeren un ile hazırlanan atıştırmalık tükettirilmiştir. Enzime dirençli nişastalı ürün tüketenlerde serum kolesterol, açlık kan şekeri, HbA1c değerleri daha düşük bulunmuş, bel çevresi ve vücut yağ oranları da benzer azalma göstermiştir. Aynı çalışmada EDN alımı ile intestinal mikroflorada değişimler, KZYA üretiminde artış olduğu da bildirilmiştir (Upadhyaya ve ark., 2016). Fırıncılık ürünlerine eklenen ve prebiyotik bir diyet lifi de olan EDN tüketiminin artırılması, sağlı̆̆ın iyileştirilmesinde ve hastalıkların tedavisinde önemli rol oynayabilir.

Enzime dirençli nişasta alımının kolonik florada Lactobacillus ve Bifidobacterium sayısını artırdığını gösteren çalışmalarda, kolon mikrobiyom çeşitliliği ve probiyotik bakterilerdeki bu artış KZYA üretimini de artırarak bağırsak mukoza kalınlığını desteklemekte ve bakteriyal geçişi azaltmaktadır (Shang ve ark., 2017; Upadhyaya ve ark., 2016). Bu etkiilerinden dolayı EDN, kabızlık, kolon kanserleri ve otoimmün hastalıkların oluşmasında azalmaya ve iyileşmeye katkı sağlayabilir.

Deney hayvanları ile yapılan bir çalışmada EDN'nin plazma kolesterol ve trigliserid (TG) seviyesini düşürmede etkili bir yöntem olduğu gösterilmiştir. Normal diyete göre tahıl nişastası \% 30 oranında EDN ile değiştirildiğinde 28 günlük beslenmenin sonunda serum kolesterolünde \% 25 azalma, TG düzeyinde ise \% 47 azalma olduğu görülmüştür (Bronkowska ve ark., 2013). Başka bir çalışmada ise fazla kilolu bireylerin olağan beslenmesine $24 \mathrm{~g} /$ gün EDN ilavesi yapılmış ve 3 hafta sonra serum kolesterol değerleri ölçülmüştür. Bireylerin vücut ağılıklarında anlamlı bir değişim olmasa da total kolesterol ve LDL kolesterol seviyeleri anlamlı olarak düşük bulunmuştur (Park ve ark., 2004). Türkiye Beslenme Rehberi (TÜBER) 2015 raporunda da belirtildiği gibi toplumun temel besini olan tahılların, EDN ile zenginleştirilmesi kalp damar hastalıkları açısından bir halk sağlığı politikası olarak uygulanabilir ve bu uygulama sağlık harcamalarının azalmasına katkı sağlayabilir.

Enzime dirençli nişasta içeren muffin tüketiminin biyokimyasal parametrelere etkisinin incelendiği bir çalışmada, 11,6 g EDN içeren muffin tüketen 28 gönüllü katılımcının, 0,9 g EDN içeren muffin tüketenlere göre tokluk kan şekeri düzeyi \% 33 daha düşük ölçülmüş, en yüksek kan şekeri ölçümlerinin ise \% 8 daha düşük olduğu gösterilmiştir. Lif oranı artan EDN'li muffinler ile tokluk insülin seviyeleri de diğer gruba göre \% 38 daha düşük cevap oluşturmuştur (Stewart ve Zimmer, 2018). Bu sonuçlar diyabetli bireylerde ağırlık kontrolünün sağlanması ve komplikasyon gelişimini yavaşlatmak açısından önemli katkı sağlayabilir.

Kronik hastalıkların daha sık görüldüğü yaşlı bireylerde EDN kullanımın etkilerinin değerlendirildiği bir araştırmada, 70 yaş üstü bireyler ile 30-50 yaş arası bireyler karşılaştırılmıştır. On iki hafta boyunca günlük $30 \mathrm{~g}$ EDN içeren prebiyotik takviyesi kullanan ve plasebo alanlar her iki grupta, grup içi ve gruplara arası karşılaştırıldığında; yaşlı bireylerde kan şekeri, insulin düzeyleri ve HOMAIR skorlarının daha düşük olduğu, gösterilmiştir. Bu çalışmada yaşlı bireylerde başlangıç seviyesine göre inflamatuar bir gösterge olan TNF- $\alpha$ 'nın da düştüğü görülmüştür. Bu sonuçlar özellikle yaşlılarda bağışıklık sistemini güçlendirmek ve kronik hastalıkların azalmasına ve iyileşmesine katkı sağlaması açısından EDN kullanımının faydalı olabileceğini göstermektedir. Ayrıca EDN'nin sindirim sistemi üzerine her iki grupta da olumsuz herhangi bir etki göstermemiştir. Bu durum sindirim açısından iyi tolerasyon olarak değerlendirilmiştir (Alfa ve ark., 2018). Sindirim tolerasyonunun iyi olması nedeniyle toplumun geneli tarafından tüketilen ürünlere EDN ilave edilmesi kabul edilebilir olacaktır.

\section{Sonuç}

Dünya nüfusunun hızla artması, yaşam sürelerinin uzaması besin kaynaklarının daha verimli kullanılmasını zorunlu hale 
getirmiştir. Yapılan araştırmalarla ortaya çıkarılan hastalık ve beslenme ilişkileri, yaşlanan nüfusla birlikte artan tedavi maliyetleri toplumun besinlerden beklentisi de artırmıştır. Tüketiciler daha sağlıklı bir hayat için sadece beslenmek amacıyla değil, kendilerine ek faydalar sağlayacak alternatif besin arayışı ile fonksiyonel besinlere yönelmektedir.

Sağlık üzerine potansiyel faydaları değerlendirildiğinde toplum sağlığı açısından, sağlıklı nesillerin sürdürülmesi için fonksiyonel besinlerin kullanımı teşvik edilmeli ve günlük beslenme düzenine dahil edilebilmelidir. Her ne kadar birçok araştırma ile bu faydalar gösterilmiş olsa da tek başına bir besinin mucize olmadığı hatırlanmalıdır. Obezite, diyabet, kalp damar hastalıkları gibi beslenme ile ilişkili hastalıklardan korunmada ve iyileşmede sağlıklı davranış modelleri geliştirilmelidir.

Bu çalışma sağlıklı beslenmek için sağlıklı besin geliştirmek amacıyla bir ön çalışma olarak yapılmıştır. Galetada uygulanan bu yöntem pek çok firın ürününde uygulanabilir ve alternatif fonksiyonel besinler geliştirilebilir.

\section{Bilgilendirme}

Çalışma kapsamında kullanılan EDN Konya'da EDN üretimi yapan Dermirpolat Şirketler Grubu'ndan temin edilmiş̧ir. Galetaların besin değerlerinin analizi için Helal Gıda Ar-Ge Merkezi’nden ve Arş. Gör. Ezgi Şenol'dan destek alınmıştır. Katkılarından dolayı teşekkür ederim.

\section{Kaynaklar}

Alfa, M.J., Strang, D., Tappia, P.S., Olson, N., DeGagne, P., Bray, D., Murlay, B., Hiebert, B. (2018). Randomized Placebo Controlled Clinical Trial to Determine the Impact of Digestion Resistance in Elderly and Mid- Age Adults. Front Med. 22;4:260.

Resistant Starch MSPrebiotic on Glucose, Insulin, and Insulin

AOAC International (2010) Official Methods of Analysis, Total Solids (total) and Moisture in Flour Air Oven Method, 925.10 / Behr Distillation Unit-S5, Almanya

Balsano, C., Alisi, A. (2009). Antioxidant effects of natural bioactive compounds. Current pharmaceutical design, 15(26), 30633073.

Bindels, L. B., Walter, J., and Ramer-Tait, A. E. (2015). Resistant starches for the management of metabolic diseases. Current opinion in clinical nutrition and metabolic care, 18(6), 559.

Bronkowska, M., Orzel, D., Lozna, K., Styczynska, M., Biernat, J., Gryszkin, A., Kapelko, M. (2013). Effect of resistant starch RS4 added to the high-fat diets on selected biochemical parameters in Wistar rats. Roczniki Państwowego Zakładu Higieny, 64 (1).

Buyken, A.E., Mela, D. J., Dussort, P., Johnson, I. T., MacDonald, I. A., Stowell, J. D., and Brouns, F. J. P.H. (2018). Dietary carbohydrates: A review of international recommendations and the methods used to derive them. Eur J Clin Nutr. Dec;72(12):16251643. doi: 10.1038/s41430-017-0035-4.

Büyüktuncel, E. (2012). Gelişmiş ekstraksiyon teknikleri I. Hacettepe Üniversitesi Eczacılık Fakültesi Dergisi, 32(2), $209-242$.

Campbell, G. M. (2008). A history of aerated foods Bubbles in Food 2 (pp. 1-21): Elsevier.

Chen, J.P., Chen, G.C., Wang, X.P., Qin, L., and Bai, Y. (2017). Dietary fiber and metabolic syndrome: A meta-analysis and review of related mechanisms. Nutrients, 10 (1), 24.

EFSA Panel on Dietetic Products, Nutrition and Allergies (NDA). (2011). Scientific Opinion on the substantiation of health claims related to resistant starch and reduction of postprandial glycaemic responses (ID 681), "digestive health benefits"(ID 682) and "favours a normal colon metabolism”(ID 783) pursuant to Article 13 (1) of Regulation (EC) No 1924/2006. EFSA Journal, 9(4), 2024.

Schmier J.K., Miller P.E., Levine J.A., Perez Vi Maki K.C., Rains T.M., Devareddy L., Sanders L.M. and Alexander D.D. Cost savings of reduced constipation rates attributed to increased dietary fiber intakes: a decision-analytic model. BMC Public Health2014,14:374

Elgün, A., Türker, S., and Bilgiçli, N. (2001). Tahıl ve ürünlerinde analitik kalite kontrolü. Selçuk Üniversitesi Ziraat Fakültesi Gıda Mühendisliği Bölümü Ders Notları. Konya Ticaret Borsası Yayın (2).

Fujii, H., Iwase, M., Ohkuma, T., Ogata-Kaizu, S.,Ide, H., Kikuchi, Y., Uchida, K. (2013). Impact of dietary fiber intake on glycemic control, cardiovascular risk factors and chronic kidney disease in Japanese patients with type 2 diabetes mellitus: the Fukuoka Diabetes Registry. Nutrition journal, 12 (1), 159.

Goñi, I., García-Alonso, A., and Saura-Calixto, F. (1997). A starch hydrolysis procedure to estimate glycemic index. Nutrition Research, 17(3), 427-437.

Guiné, R. P., Ferreira, M., Correia, P., Duarte, J., Leal, M., Rumbak, I., Sarić, M. M. (2016). Knowledge about dietary fibre: a fibre study framework. International journal of food sciences and nutrition, 67 (6), 707- 714.

Gul, K., Singh, A., and Jabeen, R. (2016). Nutraceuticals and functional foods: The foods for the future world. Critical reviews in food science and nutrition, 56(16), 2617-2627. 
Hacioğlu, G., Kurt, G., 2012. Business and Economics Research Journal Volume 3, Number 1 pp. 161-171 ISSN: 1309-2448. S:161-170.

Hasler, C.M., Bloch, A.S., Thomson, C.A., Enrione, E., Manning, C. (2004). Position of the American Dietetic Association: Functional foods. J Am Diet Assoc. 104 (5):814-26.

High Speed Analysis of Amino Acids by Pre- Column Derivatization (1999). Shimadzu Corporation, Instructions, Phenylisothiocyanate (PITC), 26922, Pierce Chemical Company, 6/1999, U.S.A.

Kranz, S., Brauchla, M., Slavin, J. L., and Miller, K.B. (2012). What do we know about dietary fiber intake in children and health? The effects of fiber intake on constipation, obesity, and diabetes in children. Advances in Nutrition, 3(1), 47-53.

Miller, J. B., Pang, E., \& Broomhead, L. (1995). The glycaemic index of foods containing sugars: comparison of foods with naturally- occurring v. added sugars. British Journal of Nutrition, 73(4), 613-623.

Miller, J. B., Pang, E., \& Broomhead, L. (1995). The glycaemic index of foods containing sugars: comparison of foods with naturally- occurring v. added sugars. British Journal of Nutrition, 73(4), 613-623.

Park, O.J, Kang, N.E., Chang, M.J., Kim, W.K. (2004). Resistant starch supplementation influences blood lipid concentrations and glucose control in overweight subjects. J Nutr Sci Vitaminol (Tokyo);Apr;50(2):93-9.

Robertson, M. D. (2012). Dietary-resistant starch and glucose metabolism. Current Opinion in Clinical Nutrition \& Metabolic Care, 15(4), 362-367.

Schmier, J. K., Miller, P. E., Levine, J. A., Perez, V., Maki, K. C., Rains, T. M., and Alexander, D. D. (2014). Cost savings of reduced constipation rates attributed to increased dietary fiber intakes: a decision-analytic model. BMC Public Health, 14 (1), 374.

Sağlık bakanlı̆̆ı Mezuatı, Türkiye Obezite (Şişmanlık) İle Mücadele Ve Kontrol Programı (2010-2014).s:15-16.

Shang W., Si, X., Zhou, Z., Li, Y., Stappappe, P., and Blanchard, C. (2017). Characterization of fecal fat composition and gut derived fecal microbiota in high-fat diet fed rats following intervention with chito-oligosaccharide and resistant starch complexes. Food \& function 8(12), 4374-4383.

Stewart, M. L., Zimmer, J. P. (2018). Postprandial glucose and insulin response to a high-fiber muffin top containing resistant starch type 4 in healthy adults: a double-blind, randomized, controlled trial. Nutrition, 53, 59-63.

TC Aile, Çalışma ve Sosyal Hizmetler Bakanlığı, Sağlıklı Yaşam Rehberi, https://www.csgb.gov.tr/media/4614/rehber 23.pdf Erişim tarihi: 11.12.2018

Türkiye'ye Özgü Beslenme Rehberi (2015); s:26-28 http://www.bdb.hacettepe.edu.tr/TOBR_kita p.pdf Erişim tarihi: 11.12.2018)

Türk Gıda Kodeksi, Etiketleme Yönetmeliği, Ek 10, 2017.

Upadhyaya, B., McCormack, L., Fardin-Kia, A.R., Junemann, R., Juenemann, R., Nichenametla, S., Clapper, J. and Dey, M. (2016). Impact of dietary resistant starch type 4 on human gut microbiota and immunometabolic functions. Scientific reports, 6, 26797.

Veronasa, N., Solmi, M., Caruso, M.G., Giannelli, G., Osella, A. R., Evangelou, E., ... \& Tzoulaki, I. (2018). Dietary fiber and health outcomes: an umbrella review of systematic reviews and meta-analyses. The American journal of clinical nutrition, 107 (3), 436444 .

Zhang, L., L1, H.T., Li, S.H.E.N., Fang, Q.C., Qian, L.L. and Jia, W.P. (2015). Effect of dietary resistant starch on prevention and treatment of obesity-related diseases and its possible mechanisms. Biomedical and Environmental Sciences, 28 (4), 291-297. 